\title{
Water Quality Assessment and Associated Stressing Factors of the Seti River Basin, Pokhara Sub Metropolitan City
}

\author{
Mandira Shrestha1, Bandana Pradhan², Ram Devi Tachamo', Deep Narayan Shah ${ }^{1}$, Subodh \\ Sharma ${ }^{3}$ and Otto Moog $^{4}$ \\ ${ }^{1}$ International Center for Integrate Mountain Development, Khumaltar, Lalitpur, GPO Box: 3226, \\ Kathmandu, Nepal. \\ Email: mshrestha@icimod.org \\ ${ }^{2}$ Department of Community Medicine \& Family Health, Institute of Medicine, Tribhuvan University, \\ Kathmandu, Nepal \\ ${ }^{3}$ Aquatic Ecology Centre, Kathmandu University, P.O. Box No. 6250, Dhulikhel, Kavre, Nepal \\ ${ }^{4}$ Department of Water, Atmosphere \& Environment, Institute for Hydrobiology \& Water Management, \\ University of Natural Resources and Applied Life Sciences, BOKU - Max Emanuel-Strasse 17, A- \\ 1180 Vienna, Austria
}

\begin{abstract}
The ASSESS-HKH Field Screening Methodology was carried out to assess the ecological river water quality status of nineteen small to medium sized rivers of the Seti River basin within Pokhara sub-metropolitan city during the lean flow period in March 2007. Multi habitat qualitative samplings for forty-six sites were conducted with $100 \mathrm{~m}$ stretch in each study river section. Five river water quality classes; class I (high), class II (good), class III (moderate), class IV (poor) and class V (bad) have been used to describe the effect of organic degradable pollution (saprobic approach). The response of benthic macroinvertebrates varied with organic pollution, sediment extraction and river crossings. The Harpan and Orlan (inlets) and Boksira (outlet) rivers of Phewa lake have water quality class III (moderately polluted) except Phirke river (outlet) which has class V. Most of the rivers outside the municipal boundaries have been identified as Class II indicating good water quality. The whole stretches of the Phusre and the Seti Rivers are still in good ecological condition. Atotal of 19 stressing factors have been identified along the river stretches, which have been grouped into five broad groups i.e., solid waste, effluent factors, activities and facilities, hydro-morphological degradation and ecological disturbances, and sanitation activity. The results are visualized by a colored water quality map which indicates the present ecological status of the Seti River basin. This map serves as an easy readable tool to identify hot spots and to show where immediate action is required. It also attracts the attention of the decision makers and enables timelymeasures to be taken for improving the deteriorating water quality of the rivers.
\end{abstract}

Key words: screening methodology, benthic macroinvertebrates, water quality, Seti River basin, river pollution

\section{INTRODUCTION}

In most Asian countries, the commonly adopted methodology for determining river water quality is mainly based on physical and chemical data. Chemical monitoring often does not account for human-caused habitat disturbance that can impair stream function. Effective monitoring programs include assessments of physical habitat and biotic integrity because the ability to sustain balanced biotic communities is a reliable indicator of stream health (Karr, 1981; Loeb and Spacie, 1994, Karr et al, 1999). Therefore, a sustainable water management and protection need to include the knowledge of bio-monitoring for sustainable management decision (Moog et. al, 2008). 
In Nepal, the river water is used for a large variety of different purposes, ranging from household (bathing, swimming and washing), livelihood means (fishing and boating), irrigation, industries, vehicular traffics and to wastes dumping. The cumulative effects of human generated stressors havenot only changed the biotic communities but also modified the river substrata and physical- morphological characteristics. As an effect of these manifold human disturbances many river sections have lost their ability of providing ecological services for the human society, eg. self purification capacity, recreational benefits and many others.

This paper attempts to provide the ecological river water quality classes represented in a water quality map with reference to organic pollution attributed by anthropogenic stressing factors of the Seti river basin located in the western development region of Nepal. The water quality map provides visual information to the river environmentalists and decision makers for conserving river stretches. If detailed programmes and strategies are made for each of the stressing factor as identified in this study, sustainable management of riverine environment and ecology can be achieved. The methodology adopted in this study can be a model for conservation planning of other river basins in the developing world (Hartmann and Moog, 2008).

\section{MATERIALS AND METHODS}

\subsection{STUDY AREA}

The Pokhara valley extends over an area of 124 $\mathrm{km}^{2}$ and lies at an average elevation of $725 \mathrm{~m}$ asl. The Pokhara basin is filled with gravel, and lacks entirely lacustrine deposits such as lignites (Gurung, 1970). It receives the largest amount of rainfall in Nepal with an annual average rainfall of about 3,600 millimetres. The Setiand its major tributary the Mardi are glacier-fed streams on the south slopes of Annapurna Himal and therefore their headwaters lie outside the Pokhara basin (Gurung, 1970). The Seti's tributaries; Bijayapur, Yamgdi, Marse, Khudi, Dobhan, Kali, Bhurjung, Anpu, Kahun, and Gabadi are spring or rain-fed perennial streams. The Seti

Journal of Hydrology and Meteorology, Vol.6, No. 1 flows through deep narrow gorges with depth of over $46 \mathrm{~m}$ at some location. There are large-scale slips and cracks along the banks, which sometimes coalesce to make the Seti a subterranean river.

For this study the Seti River and its tributaries that flow through the Pokhara sub-metropolitan city were considered for the ecological assessment. The city lies between $83^{\circ} 58^{\prime} 30^{\prime \prime} \mathrm{E}$ to $80^{\circ} 02^{\prime} 30^{\prime \prime} \mathrm{E}$ longitude and $28^{\circ} 10^{\prime} \mathrm{N}$ to $28^{\circ} 16^{\prime} \mathrm{N}$ latitude. It occupies an area of $55.66 \mathrm{~km}^{2}$ within the Pokhara tectonic valley. It has humid sub-tropical monsoon with hot and wet summer and cold and fairly dry winter. According to the 2001 census the population of the city was 156,312 which is projected to be 248,974 in 2008 . The population density of the city is 3848.83 persons per sq. $\mathrm{km}$ with a large number of people migrating into the city. Its average annual population growth rate is $7.41 \%$.

\subsection{SITE SELECTION}

A total of 46 investigation sites were selected for biological water quality assessment in the Seti river and its tributaries (Table 1). Site selection was based on the point of effluent discharge, landuse, solid waste disposal, bank condition, substrate composition, and location of tributaries.

\section{METHODS}

\subsection{SAMPLING:}

The qualitative sampling followed the ASSESSHKH multi-habitat approach (Moog, 2006). Ten sampling units were taken in $10 \mathrm{~m}$ stretch of each river segment. Benthic macroinvertebrates samples were collected with sampling net of $500 \mathrm{~mm}$ mesh size from the most downstream point of the investigated section, identified up to family level and recorded with abundance of each sample unit in the screening protocol (Hartmann and Moog, 2008) as presented in Appendix 1a. The successive samples were taken for further addition of taxa. The protocol is based on both, the sensory criteria and benthic invertebrates that can be identified in field. Finally, screening protocol provides sum up values from both criterion that determine water 
quality class of the study section directly on the spot. The sample was preserved in $4 \%$ formaldehyde in the field. In addition, hydro-morphological characteristics, physical characteristics of river ecosystem and their impacting factors were filled in the site protocol (Korte and Moog, 2006).

Table 1: Sampling sites in different river/ streams of Seti River basin, Pokhara.*

\begin{tabular}{|l|c|c|c|c|c|}
\hline \multicolumn{1}{|c|}{$\begin{array}{c}\text { Stream/ } \\
\text { river name }\end{array}$} & $\begin{array}{c}\text { No. of } \\
\text { sites }\end{array}$ & $\begin{array}{c}\text { Stream/ } \\
\text { river } \\
\text { name }\end{array}$ & $\begin{array}{c}\text { No. of } \\
\text { sites }\end{array}$ & $\begin{array}{c}\text { Stream/ } \\
\text { river } \\
\text { name }\end{array}$ & $\begin{array}{c}\text { No. of } \\
\text { sites }\end{array}$ \\
\hline $\begin{array}{l}\text { Seti main } \\
\text { Stretch }\end{array}$ & 7 & $\begin{array}{c}\text { Dhad } \\
\text { Khola }\end{array}$ & 1 & $\begin{array}{c}\text { Pardi } \\
\text { Khola }\end{array}$ & 3 \\
\hline $\begin{array}{l}\text { Tributaries of } \\
\text { Seti }\end{array}$ & $\begin{array}{l}\text { Gharmi } \\
\text { Khola }\end{array}$ & 1 & $\begin{array}{c}\text { Phirke } \\
\text { Khola }\end{array}$ & 4 \\
\hline Ambot Khola & 1 & $\begin{array}{c}\text { Harpan } \\
\text { Khola }\end{array}$ & 1 & $\begin{array}{c}\text { Phusre } \\
\text { Khola }\end{array}$ & 4 \\
\hline $\begin{array}{l}\text { Bhalam } \\
\text { Kholal I }\end{array}$ & 2 & $\begin{array}{l}\text { Kahu } \\
\text { Khola }\end{array}$ & 3 & Sedi Khola & 1 \\
\hline $\begin{array}{l}\text { Bijaypur } \\
\text { Khola }\end{array}$ & 7 & $\begin{array}{c}\text { Kali } \\
\text { Khola }\end{array}$ & 3 & $\begin{array}{c}\text { Syani } \\
\text { patan } \\
\text { Khola }\end{array}$ & 1 \\
\hline $\begin{array}{l}\text { Bulaudi } \\
\text { Khola }\end{array}$ & 2 & $\begin{array}{c}\text { Khahare } \\
\text { Khola }\end{array}$ & 2 & Yamdi & 1 \\
\hline Bulbul Khola & 1 & $\begin{array}{l}\text { Orlan } \\
\text { Khola }\end{array}$ & 1 & Canals & 5 \\
\hline
\end{tabular}

${ }^{*}$ Results of canals are not included in this paper

\subsection{LABORATORY ANALYSIS:}

After at least one week of fixation, samples were further processed in the lab through sorting and identification based on keys (Nesemann et al. 2007, Yule, 2004, and unpublished keys 2006 of ASSESS HKH project). The additional taxa were included in the taxa list prepared in the field. This final macroinvertebrates list were assigned with NEPBIOS score (Appendix 1b) and calculated NEPBIOS ASPT in order to obtain the River Water Quality Classification (RWQC) and was verified with field water quality classes resulted from screening protocol.

\subsection{CORRIDOR SURVEY:}

For the selected river stretch, the sketch of the river section was drawn. The features of the river such as bank condition and structure, bed materials, riparian vegetation, flood plain land use, flow conditions like pool, riffles, runs, rapids, water fall, slacks, and stressors like sewage discharge, substrates abstraction, water abstraction, solid waste disposal, washing, bathing and river engineering were noted down.

\section{RESULTS}

\subsection{TAXA RICHNESS AND COMPOSITION}

Altogether 81 taxa based on family level identification were recorded from the Seti River basin in which $80.24 \%$ contributed by Arthropoda phyla only. Diptera alone contributed $22.22 \%$ followed by $13.58 \%$ Trichoptera and $12.35 \%$ Heteroptera among recorded benthic invertebrates.

\subsection{SENSORIC FEATURES}

Foam, odour, non-natural colour, sewage fungi were present in river stretches from class III. Solid wastes and reduction phenomenon were observed in moderate to bad quality classes, however, solid wastes was also present in good water quality in trace amount. Filamentous green algae and \% thick significant layers of algae were more abundant in class II and III. Stones with thin algal vegetation were present in only class I and II.

\subsection{STRESSORS DETERIORATING WATER QUALITY}

Based on the data and information contained in the field protocol sheet and corridor survey, description of major riverine features together with stressing factors is summarised in Table 2. The following observations were obtained: The water of the rivers all across the stretches is found to be used for multiple purposes like drinking, washing, bathing, and irrigation. The river water is found to be used for drinking in class I through class II. According to the description of the water quality, class II cannot be used directly for drinking purpose, as the rivers contain effluents, such as solid waste, agricultural chemical residues and industrial gutter. The four major stressing factors found in the basin are waste dumping, bathing and washing, sewage and channel, embankment \& weir. The number and types of these stressing factors are intensified in class II and other ascending classes. 
Table 2: Major stressing factors of the Seti River basin by Water Quality Class

\begin{tabular}{|c|c|c|c|c|c|}
\hline \multirow{2}{*}{ Description } & \multicolumn{5}{|c|}{ Water Quality Classes } \\
\hline & I & II & III & IV & V \\
\hline Water use & $\begin{array}{l}\text { None, } \\
\text { tapped in } \\
\text { reservoir, } \\
\text { drinking, } \\
\text { irrigation, } \\
\text { washing }\end{array}$ & $\begin{array}{l}\text { irrigation, bathing and } \\
\text { washing \& drinking } \\
\text { (animals) }\end{array}$ & $\begin{array}{l}\text { Bathing , washing } \\
\text { and Irrigation, } \\
\text { fishing, boating , } \\
\text { animal wallow }\end{array}$ & $\begin{array}{l}\text { Bathing, washing } \\
\text { and Irrigation, fishing, } \\
\text { boating, animal } \\
\text { wallow }\end{array}$ & - \\
\hline Effluents & None & $\begin{array}{l}\text { Domestic, agriculture } \\
\text { and industry, leachate } \\
\text { from land-filled }\end{array}$ & $\begin{array}{l}\text { Domestic, } \\
\text { agriculture and } \\
\text { industry }\end{array}$ & $\begin{array}{l}\text { Domestic, agriculture } \\
\text { and industry }\end{array}$ & $\begin{array}{l}\text { Domestic, agriculture } \\
\text { and industry }\end{array}$ \\
\hline $\begin{array}{l}\text { Stressing } \\
\text { factors }\end{array}$ & $\begin{array}{l}\text { Reference } \\
\text { site } \\
\text { (minimum } \\
\text { anthropogen } \\
\text { ic impacts) }\end{array}$ & $\begin{array}{l}\text { Stone quarrying and } \\
\text { mining, vehicle } \\
\text { crossing, waste } \\
\text { dumping, embankment, } \\
\text { open defecation, } \\
\text { agricultural runoff, } \\
\text { impoundment, bank } \\
\text { erosion and flood, } \\
\text { fishing, natural } \\
\text { suspended loads }\end{array}$ & $\begin{array}{l}\text { Sand extraction, } \\
\text { waste dumping, } \\
\text { squatter } \\
\text { settlements, } \\
\text { irrigation, } \\
\text { agricultural runoff, } \\
\text { vehicle crossing, } \\
\text { weir and } \\
\text { embankment; water } \\
\text { pools \& fish } \\
\text { catching }\end{array}$ & $\begin{array}{l}\text { Sand extraction, } \\
\text { waste dumping, } \\
\text { squatter settlements, } \\
\text { irrigation, agricultural } \\
\text { runoff, vehicle } \\
\text { crossing, weir and } \\
\text { embankment; water } \\
\text { pools \& fish catching }\end{array}$ & $\begin{array}{l}\text { Wastewater effluents, } \\
\text { waste disposal; bank } \\
\text { encroachment; open } \\
\text { defecation }\end{array}$ \\
\hline Settlements & $\begin{array}{l}\text { None to } \\
\text { sparse }\end{array}$ & Sparse to medium & Sparse to medium, & Sparse to medium & Dense \\
\hline Development & None & Weir & $\begin{array}{l}\text { agricultural fields, } \\
\text { vehicle crossing }\end{array}$ & $\begin{array}{l}\text { agricultural fields, } \\
\text { vehicle crossing }\end{array}$ & $\begin{array}{l}\text { Concrete embankment, } \\
\text { roads on the banks and } \\
\text { waste dumping }\end{array}$ \\
\hline Bank fixation & $\begin{array}{l}\text { None, } \\
\text { natural } \\
\text { embankment }\end{array}$ & Natural, channelization & $\begin{array}{l}\text { None, concrete and } \\
\text { bamboo } \\
\text { embankments, } \\
\text { channelization }\end{array}$ & $\begin{array}{l}\text { None, concrete and } \\
\text { bamboo } \\
\text { embankments, } \\
\text { channelization }\end{array}$ & - \\
\hline
\end{tabular}

Source: Field Survey, 2007

\section{DISCUSSION}

The number of taxa ranged from 21-34, 11-34, 931, 6-12 and 6-9 for RWQCs I, II, III, IV and V respectively. The mean number of taxa decreased gradually from RWQC I to V. Plecopteran taxa was absent from class III onwards where as EPT taxa completely disappeared from class $\mathrm{V}$ as shown in Table 3. Ephemeroptera except Baetidae and Trichoptera except Hydropsychidae have shown remarkable significance with WQCs. Baetidae and Hydropsychidae were observed from class I- IV due to facultative nature with pollution
Table 3: Distribution of macroinvertebrates by saprobic water quality class

\begin{tabular}{|l|l|l|l|l|l|}
\hline \multirow{2}{*}{\multicolumn{1}{|c|}{ Group }} & \multicolumn{5}{|c|}{ Average number of families } \\
\cline { 2 - 7 } & I & II & III & IV & V \\
\hline Ephemeroptera & 4 & 4 & 2 & 1 & - \\
\hline Plecoptera & 1 & 1 & - & - & - \\
\hline Trichoptera & 2 & 2 & 3 & 1 & - \\
\hline Coleoptera & 2 & 2 & 2 & 1 & - \\
\hline Heteroptera & 1 & 2 & 2 & 1 & - \\
\hline Odonata & 2 & 2 & 2 & 3 & 3 \\
\hline Diptera & 3 & 4 & 4 & 2 & 2 \\
\hline Megaloptera & 1 & 1 & - & - & - \\
\hline Lepidoptera & 1 & - & - & - & - \\
\hline Decapoda & 2 & 1 & 2 & - & - \\
\hline Tricladida & 1 & 1 & 1 & 1 & - \\
\hline Oligochaeta & 1 & 2 & 2 & 3 & 2 \\
\hline Bivalvia & 2 & 1 & 1 & 1 & 1 \\
\hline Gastropoda & 2 & 2 & 2 & 2 & 2 \\
\hline EPT Taxa & 7 & 7 & 5 & 2 & - \\
\hline
\end{tabular}




\subsection{SAPROBIC WATER QUALITY CLASS}

Assessment of Setibasin resulted in five river water quality classes ranging from I (high) to V (bad). Ambote, Bijyapur and Pardi Rivers are of class I while entering the municipal boundaries (Figure 1). The catchment of class I and II rivers stretches were found completely different than catchment area described by Shah et. al, (2008) that are attributed with larger river width, without significant foliage covers and easily accessible to human. Seti and Phusre rivers maintain class II all along their stretches. The Phirke river that passes through the core city area of the municipality is highly polluted and is categorized as class V. The river quality map for five quality classes is constructed and the quality classes have been depicted by different indicative colours such as blue for RWQC I, green for RWQC II, yellow for RWQC III, orange for RWQC IV, and red for RWQC V. The water quality map for the Seti River basin was prepared in Google Earth Map and is shown in Figure 1.

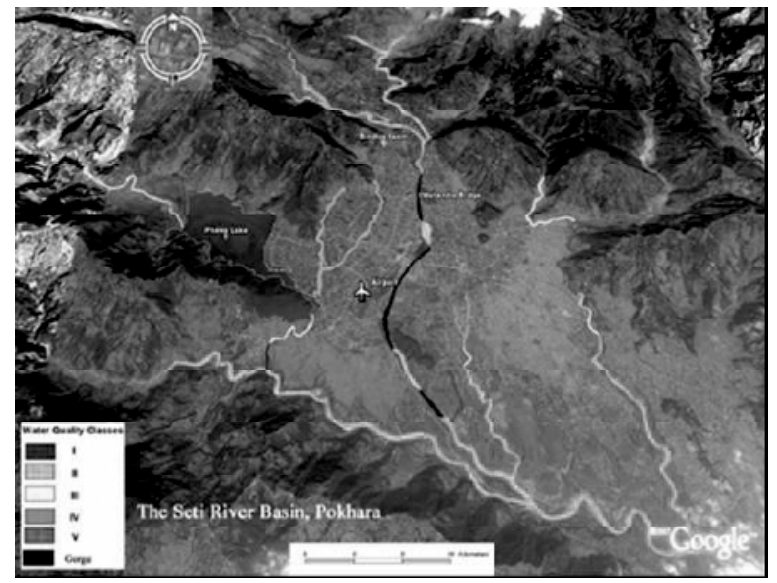

Figure 1: Water Quality Classes on Google Map

A relationship between water quality class and density of settlements is observed along the river stretches. The density of settlements is thin in the upstream area where water quality is class I, and the river water quality is found to be degraded (as indicated in other ascending water quality classes) as is intensified in the density of settlements in downwards along the river stretches. The anthropogenic activities (stressors) related to development like roads, embankment, reservoir, agricultural intensification, vehicular traffic, sand or stone quarrying, are found to be increased both in volume and type in downstream areas.

Table 4: Classification of the River Quality Stressing Factors

\begin{tabular}{|c|c|c|}
\hline Group & Stressing factors & $\begin{array}{l}\text { Seti Basin } \\
(f)\end{array}$ \\
\hline \multirow{3}{*}{$\begin{array}{l}\text { A. Solid } \\
\text { Waste }\end{array}$} & - Waste dumping & 40 \\
\hline & - Cremation site & 2 \\
\hline & Sub-total & $42(31.3 \%)$ \\
\hline \multirow{5}{*}{ B. Effluents } & - Sewage & 15 \\
\hline & - Agricultural effluent & \\
\hline & - Industrial effluent & 3 \\
\hline & - Landfill leachate & 1 \\
\hline & Sub-total & $22(16.4 \%)$ \\
\hline \multirow{5}{*}{$\begin{array}{l}\text { C. Activities } \\
\text { and facilities }\end{array}$} & $\begin{array}{l}\text { - Squatter } \\
\text { settlements }\end{array}$ & 2 \\
\hline & $\begin{array}{l}\text { - Picnic spots close } \\
\text { to river }\end{array}$ & 2 \\
\hline & $\begin{array}{l}\text { Vehicle crossing } \\
\text { along river or using } \\
\text { rivers as roads }\end{array}$ & 2 \\
\hline & $\begin{array}{l}\text { - Littering by picnic } \\
\text { goers }\end{array}$ & 1 \\
\hline & Sub-total & $7(5.2 \%)$ \\
\hline \multirow{8}{*}{$\begin{array}{l}\text { D. Hydro } \\
\text { morphological } \\
\text { degradation } \\
\text { \& ecological } \\
\text { disturbances }\end{array}$} & $\begin{array}{l}\text { - Channel, } \\
\text { embankment \& weir }\end{array}$ & 12 \\
\hline & - Bank cutting & 1 \\
\hline & $\begin{array}{l}\text { - Reservoir, dam \& } \\
\text { impoundment }\end{array}$ & 7 \\
\hline & - Irrigation & 3 \\
\hline & - Fishing \& boating & 3 \\
\hline & $\begin{array}{l}\text { - Stone quarrying \& } \\
\text { crushing }\end{array}$ & 2 \\
\hline & - Sand quarrying & 6 \\
\hline & Sub-total & $34(25.4 \%)$ \\
\hline \multirow{3}{*}{$\begin{array}{l}\text { E. Personal } \\
\text { hygiene and } \\
\text { sanitation }\end{array}$} & - Bathing \& washing & 24 \\
\hline & - Open defecation & 5 \\
\hline & Sub-total & $29(21.6 \%)$ \\
\hline & Total & $134(100 \%)$ \\
\hline
\end{tabular}

Source: Field Survey, 2007

Because of higher intensification, they are responsible to degrade water quality at the sample sites in upstream-downstream areas. Along with the intensity of activities, conservation of river 
environment has also been observed. Embankment of the river banks with bamboo and cemented wall, channelization, and buffer corridor are some major conservation activities found along the river stretches. However, at the same time, some of these activities like cement embankment and channelization are not considered to be river ecofriendly measures.

A total of 19 stressing factors have been identified along the river stretches, which have been grouped in to five broad groups solid waste, effluents, activities and facilities, hydromorphological degradation and ecological disturbances and sanitation activity (Table 4 ). The relative importance of solid waste (waste dumping and cremation) is the largest, with about 31.3 percent. While the relative importance of 'Group-D', i.e. hydro morphological degradation and ecological disturbances (26.1\%), is the second largest stressing factor and relative importance of 'Group-C' is the least stressing factor for the Seti basin.

\section{CONCLUSION}

The Seti River basin has maintained good water quality class. The inlets and outlets of Pokhara valley is of class II. The Phirke river that passes through the city has bad water quality (class V) at the outlet with low volume of water during the low flow season. The outlet of Phewa lake (Boksira River) had class III as same to inlets (Harpen and Orlan rivers). Thus, Phirke has no significant impact in lake as well as overall water quality of Seti river basin.

It is found that the river water has been used for different purposes, ranging from household (bathing, swimming and washing) to livelihood means (fishing), as well for irrigation, industries, and traffics and for waste dumping. The major stressing environmental factors for the deterioration of the riverine ecology are waste dumping, bathing and washing, sewage and channelization. There exists a relationship between the number and types of the stressing factors and water quality classes, which is indicated by an increase in intensification of anthropogenic impacts along with the ascending order of poor water quality classes. It is important however to establish relationship between these two indicators by in-depth study.

The results of impacts of the stressing factors however provide valuable information to the river environmentalists and decision makers for conserving river stretches. The methodology adopted in this study can be replicated for other river basins for water quality monitoring, conserving and planning.

\section{ACKNOWLEDGEMENTS}

We thank the project "Development of an Assessment System to Evaluate the Ecological Status of Rivers in the Hindu Kush-Himalayan Region" (ASSESS-HKH) for supporting this study. The project is funded by European Union (INCOCT-2005-003659).

\section{REFERENCES:}

Gurung, H.B., 1970. Geomorphology of Pokhara Valley, Himalayan Review, 2-3, pp. 3749

Hartmann, A. and O. Moog, 2008. Development of a field screening methodology to evaluate the ecological status of the streams in the HKH region. In: proceedings of Scientific Conference on Rivers in the Hindu Kush Himalaya: Ecology and Environmental Assessment. (Eds) O. Moog, D. Hering, S. Sharma, I. Stubauer and T. Korte. pp. 17-24.

Karr, JR., 1981. Assessment of biotic integrity using fish communities. Fisheries 6, 21-26.

Karr, J.R., and E.W. Chu, 1999. Restoring life in running waters: better biological monitoring. Island Press, Washington, D.C. 
Korte T. and O. Moog, 2006. Manual for the application of the ASSESS HKH site protocol. ASSESS HKH Project. http:// www.assess-hkh.at/mains/products.php

Loeb S.L. and A. Spacie, editors. 1994. Biological monitoring of aquatic systems. Boca Raton (FL): Lewis Publishers; 318 Pp.

Moog, O., 2006. Deliverable No. 8- Part 1, Manual on pro-rata Multi-Habitat-Sampling of benthic invertebrates from wadable rivers in the $\mathrm{HKH}$ region. ASSESS HKH Project. http://www.assess-hkh.at/mains/ products.php

Moog, O., D. Hering, T. Korte, S. Sharma, I. Stubauer, 2008. Sustainable water management needs to be based on a sound scientific fundament. In: proceedings of Scientific Conference on Rivers in the Hindu Kush Himalaya: Ecology and Environmental Assessment. (Eds) O. Moog, D. Hering, S. Sharma, I. Stubauer and T. Korte. Pp. 3-4
Nesemann, H., S. Sharma, G. Sharma, S. Khanal, B. Pradhan, D. N. Shah, R. D. Tachamo, 2007. Aquatic Invertebrates of the Ganga River System, Vol. 1. Kathmandu, Nepal.

Shah, D.N., R.D. Tachamo, H. Nesemann, and S. Sharma, 2008. Water quality assessment of drinking water sources in the mid-hills of central Nepal. Journal of Hydrology and Meteorology. 5(1), pp73-78.

Sharma, S., 1996. Biological assessment of water quality in the rivers of Nepal. PhD dissertation.-University of Natural Resources and Applied Life Sciences, Vienna, Austria.

Yule, C.M., 2004. Freshwater Environments. In Yule, C.M. and Sen, Y.H. (Eds.): Freshwater Invertebrates of the Malaysian Region. Academy of Sciences Malaysia Publishers, Malaysia. 
Appendix 1a:

Screening Protocol for assessing the river quality of streams in the ASSESS-HKH (version Moog 12/03/07) exceptive Gangetic Plains

\begin{tabular}{|c|c|c|}
\hline $\begin{array}{l}\text { River: } \\
\text { Site: } \\
\text { N: } \\
\text { Temperature water: }\end{array}$ & $\begin{array}{l}\text { River system: } \\
\text { Next village: } \\
\text { E: } \\
\text { Conductivity: }\end{array}$ & $\begin{array}{l}\text { Date/Time: } \\
\text { Surveyor: } \\
\text { Altitude }(\mathrm{m}) \text { : }\end{array}$ \\
\hline
\end{tabular}

\begin{tabular}{|c|c|c|c|c|c|}
\hline \multirow{2}{*}{\begin{tabular}{|l} 
DECISION SUPPORT TABLE \\
Multiple choices possible
\end{tabular}} & \multicolumn{5}{|c|}{ WATER QUALITY CLASSES } \\
\hline & $\mathrm{T}$ & II & IIII & IV & $\overline{\mathbf{V}}$ \\
\hline Sensory features & \multicolumn{5}{|c|}{ To be ticked/counted if not in accordance with natural river type } \\
\hline Non natural turbidity, Suspended solids & & & + & + & ++ \\
\hline Non natural colour & & + & + & + & ++ \\
\hline Foam & & + & + & + & + \\
\hline Odour (water) & & + & ++ & ++ & ++ \\
\hline Waste dumping & & + & + & + & + \\
\hline Ferro-sulphide reduction - (water velocity $<0,25 \mathrm{~m} / \mathrm{s}$ ) & - & & & & \\
\hline Mud reduced but with aerobic surface & & + & +++ & ++ & \\
\hline Mud reduced but with anaerobic surface & & & & ++ & +++ \\
\hline Lower surface of stones (\% cover black dots) & & $<25 \%$ & $25-75 \%$ & $75-100 \%$ & $100 \%$ \\
\hline Upper \& lower surfaces of stones ( $\%$ cov. black dots) & & & & + & ++ \\
\hline Ferro-sulphide reduction - (water vel.) $0,25-0,75 \mathrm{~m} / \mathrm{s}$ ) & - & - & & & \\
\hline Mud reduced but with aerobic surface & & & + & ++++ & + \\
\hline Mud reduced but with anaerobic surface & & & & + & ++ \\
\hline Lawer surface of stones (\% cover black dots) & & & $<50 \%$ & $50-100 \%$ & $100 \%$ \\
\hline Upper \& lower surfaces of stones ( $\%$ cov. black dots ) & & & & & +++ \\
\hline \multicolumn{6}{|l|}{ Ferro-sulphide reduction - (water velocity $>0,75 \mathrm{~m} / \mathrm{s}$ ) } \\
\hline Lawer surface of stones (\% cover black dots) & & & $<25 \%$ & $25-50 \%$ & $50-100 \%$ \\
\hline Upper \& lower surfaces of stones ( $\%$ cov. black dots) & & & & & +++ \\
\hline \multicolumn{6}{|l|}{ Bacteria, fungi. periphyton } \\
\hline Sewage fungi \& bacteria (visible to the naked eyes) & $(-)$ & $(-)$ & few & medium & many +++ \\
\hline Sulphur bacteria (visible to the naked eyes) & $(-)$ & $(-)$ & $(-)$ & + & +++ \\
\hline Stones with algal vegetation (periphyton) in thin layers & ++ & ++ & & & \\
\hline$\psi_{v}$ of thick, significant layers of algae & $<25 \%$ & $25-75 \%$ & $75-100 \%$ & $75-100 \%$ & few \\
\hline Filamentous green algae & none to few & filaments, tufts & large tufts & (large) tufts & + \\
\hline \multicolumn{6}{|l|}{ Benthic macro-invertebrates } \\
\hline Species richness & medium/high & (very) high & medium & few & very few"- \\
\hline Dominance of very sensitive organisms $\left.(8 \text { to } 10)^{*}\right)$ & +++ & & & & \\
\hline Dominance of sensitive organisms ( 6 to 8$)^{\circ}$ ) & + & +++ & + & & \\
\hline Dominance of medium tolerant organisms $\left.(4 \text { to } 6)^{*}\right)$ & & & +++ & + & \\
\hline Dominance of tolerant organisms $\left.(3 \text { to } 4)^{*}\right)$ & & & + & +++ & + \\
\hline Dominance of extremely tolerant organisms (1 to 2$)^{*}$ ) & & & & & +++ \\
\hline Potamldae & ++ & ++ & + & & \\
\hline Perlidae & ++ & + & & & \\
\hline Plecoptera & ++ & + & & & \\
\hline Heptageniidae & +++ & ++ & + & & \\
\hline Rhithrogena spp. & +++ & ++ & & & \\
\hline Ephemerellidae & + & ++ & + & & \\
\hline Euphaeidae & ++ & + & & & \\
\hline Stenopsyche spp. & + & ++ & & & \\
\hline Lepidostomatidae & + & ++ & + & & \\
\hline Rhyacophila SpP. & ++ & + & & & \\
\hline Simuliidae & + & ++ & ++ & & \\
\hline Tabanidae & & + & ++ & ++ & \\
\hline Hydropsyche spp. (medium to many) & & + & +++ & + & \\
\hline Physa spp. (medium to many) & & & + & ++ & \\
\hline Leeches (more than naturally occurring) & - & - & + & +++ & + \\
\hline Chironomids with red colour & & very few & few & medium & +++ many ${ }^{* *}$ \\
\hline Bezzia-Group & & & & + & ++ \\
\hline Psychodidae white & & & & + & +++ \\
\hline Air-breathing animals, e. g. rat-tail maggots & & & & & +++ \\
\hline Oligochaeta / Tubificidae (mud-worms) & 0 to very tew & tew & tew/medium & medium/many & many"x \\
\hline Sum of columns & & & & & \\
\hline
\end{tabular}


Appendix 1b: NEPBIOS Score modified after Sharma

\begin{tabular}{|c|c|c|c|c|c|c|c|}
\hline TAXON / NEPBIOS & & Abd & TAXON / NEPBIOS & & Abd & HABITAT & $\%$ \\
\hline Aeshnidac & 6 & & Limnocentropodidae & 9 & & Mineral & \\
\hline Aphelocheiridae & 7 & & Limoniidae & 8 & & Hygropetric & \\
\hline Athericidae & 10 & & I ymnaeidae & 6 & & Boulders & \\
\hline Baetidae & 7 & & Micronecta & 4 & & Cobbles & \\
\hline Bezzia-Group & 2 & & Muscidae & 3 & & Stones & \\
\hline Bithyniidae & 5 & & Naucoridae & 4 & & Pebbles & \\
\hline Blephariceridae & 10 & & Nemouridae & 9 & & Gravel & \\
\hline Brachycentridae & 7 & & Neoephemeridae & 9 & & Sand & \\
\hline Caenidae & 6 & & Nepidae & 4 & & Sandy mud & \\
\hline Ca opterygidae & 1 & & Noteridae & 4 & & Mud & \\
\hline Chironomidae red & 1 & & Notonectidae & 3 & & Clay & \\
\hline Chironomidae not red & 5 & & Odontoceridae & 5 & & & \\
\hline Chorocyphidae & 9 & & Palaemonidae & 4 & & Biotic & \\
\hline Choroperlidae & 5 & & Peltoperlidae & 10 & & Micro algae & \\
\hline Coenagrionidae & 4 & & Perlidae & 8 & & Macro algae & \\
\hline Corbiculidae & 5 & & Perlodidae & 9 & & Submerged macroph. & \\
\hline Corduliidae & 4 & & Philopotamidae & 7 & & Emerged makrophyte & \\
\hline Corixidae & 6 & & Physidae & 3 & & Living terrest. plants & \\
\hline Corydalidae & 2 & & Planariidae & & & Wood & \\
\hline Cu icidae & 5 & & Planorbidae & 4 & & CPOM & \\
\hline Dryopidae & 4 & & Pleuroceridae & 4 & & FPOM & \\
\hline Dytiscidae & 6 & & Polycentropodidae & 7 & & Debris & \\
\hline Ecnomidae & 8 & & Potamidae & 7 & & Sewage bacteria & \\
\hline Elmidae & 7 & & Protoneuridae & 5 & & & \\
\hline Ephemerellidae & 6 & & Psephenidae & 7 & & & \\
\hline Ephemerellidae (Drunel. sp.) & 7 & & Psychodidae (white) & 2 & & & \\
\hline Ephemeridae & 10 & & Psychomyiidae & 6 & & & \\
\hline Epiophlebiidae & 8 & & Ranatridae & 4 & & & \\
\hline Euphaeidae & 7 & & Rhyacophilidae & 8 & & & \\
\hline Gammaridae & 4 & & Salifidae & 3 & & & \\
\hline Gerridae & 4 & & Scirtidae & 8 & & & \\
\hline Glossiphoniidae & 7 & & Simuliidae & 7 & & & \\
\hline Glossosomatidae & 9 & & Siphlonuridae & 10 & & & \\
\hline Goeridae & 4 & & Sphaeriildae & 5 & & & \\
\hline Gomphidae & 6 & & Stenopsychidae & 6 & & & \\
\hline Gyrinidae & 10 & & Stratiomyidae & & & & \\
\hline He icopsychidae & 10 & & Taeniopterygidae & 10 & & & \\
\hline Heptageniidae & 10 & & Tabanidae & 2 & & & \\
\hline Heptageniidae (Epeorus sp.) & 9 & & Thiaridae & 4 & & & \\
\hline Heptageniidae (Iron sp.) & 9 & & Tipulidae & 8 & & & \\
\hline Hept. (Rhithrogena sp.) & 8 & & Tubificidae & 1 & & & \\
\hline Hydraenidae & 6 & & Veliidae & 4 & & & \\
\hline Hydraenidae (Ochthebius sp.) & 10 & & & & & & \\
\hline Hydrobiosidae & 10 & & Other Taxa $\mathbb{Z}$ & & & & \\
\hline Hydrometridae & 6 & & & & & & \\
\hline Hydrophilidae & 6 & & & & & & \\
\hline Hydropsychidae & 6 & & & & & & \\
\hline Hydroptilidac & 10 & & & & & & \\
\hline I epidostomatidae & 5 & & & & & & \\
\hline Leptoceridae & 7 & & & & & & \\
\hline Leptophlebiidae & 10 & & & & & & \\
\hline Leuctridae / Capniidae & 6 & & & & & & \\
\hline Libellulidae & 6 & & & & & & \\
\hline Limnephilidae & 9 & & & & & & \\
\hline
\end{tabular}

